\title{
A Study of The Ideal Home Space Needs of Urban Millennials Families, Based on Life Cycle Space (Case Study of Housing in East Denpasar)
}

\author{
Made Suryanatha Prabawa ${ }^{1}$, A.A. Gede Raka Gunawarman ${ }^{2}$ \\ \{nathaprabawa.np@gmail.com ${ }^{1}$, dapurpoleng@gmail.com²
}

Program Studi Arsitektur Universitas Warmadewa, Denpasar, Indonesia

\begin{abstract}
A home is very important in terms of developing a healthy family and a good community. In this case, Denpasar is a city that continues to grow in terms of city population (3.83\% per year). Millennial population currently reaches $1 / 3$ of the total population in Indonesia and they are very active individuals in digital media. However, the Industrial Revolution 4.0 has changed the way the millennial defines themselves and also changed the way they live in this world. This is due to their active connection with gadgets and social media. The problem in this study is how large conventional homes can provide comfort spaces for millennials, especially those who are married with children. Therefore, this research uses a qualitative method with literature study, questionnaire, and interviews to get information. Based on surveys and analysis, it was discovered that many millennial families change their rooms in terms of functional needs. They creatively change the way they use conventional spaces depending on their professions such as photographers, online merchants, and freelance architects who needs to work from home. Why they do this? It is because effective communication with clients can be done through social media and other communication applications on the phone. Furthermore, while they are working, they can also monitor their children and freely do other things like hobbies.
\end{abstract}

Keywords: Housing, Family Millennials, Functional Needs

\section{Pendahuluan}

Rumah merupakan salah satu dari kebutuhan pokok manusia. Menurut UU no. 4 Tahun 1992 Tentang Perumahan dan Permukiman, rumah adalah bangunan yang berfungsi sebagai tempat tinggal atau hunian dan sarana pembinaan keluarga. Kota Denpasar sebagai ibukota Provinsi Bali merupakan Kota yang terus mengalami pertambahan penduduk sejumlah 3.83\% / tahun (Denpasar Dalam Angka, 2018) diakibatkan oleh adanya arus Urbanisasi 
maupun Transmigrasi. Dari seluruh penduduk Kota Denpasar khususnya kecamatan Denpasar timur, terdiri dari kelompok umur yang beragam. Pada dasarnya masing-masing kelompok umur memerlukan kebutuhan ruang dalam rumah yang berbeda-beda menurut aktivitas ataupun gaya hidupnya atau biasa disebut ruang daur hidup. Kaum milenial sebagai fokus subjek penelitian arsitektural merupakan kaum yang hangat dibahas dewasa ini, akibat keterkaitan perannya terhadap revolusi industri 4.0. Definisi Kaum Milenial adalah generasi yang lahir mulai tahun 1988 -2000 yang mana saat ini generasi ini adalah masyarakat berumur 15 - 35 tahun. Kaum milenial saat ini menduduk 1/3 Jumlah Penduduk di Indonesia dan merupakan kaum yang bercirikan sangat aktif pada dunia digital. Keberadaan kaum milenial ini juga berkaitan dengan terjadinya Revolusi Industri 4.0. Revolusi Industri 4.0 memiliki ciri hadirnya kecerdasan buatan (artificial inteligence) seperti teknologi berbasis internet (internet of things), nanoteknologi, printer 3D, komputasi kuantum, dsb. Revolusi industri ini mengubah cara kaum milenial mendefinisikan siapa mereka dan dunia yang mereka tempati. Akibat dari perspektif tersebut adalah dunia menjadi digital dan peristiwa dunia menjadi "kekinian", dimana ruang dan waktu terkompresi dan kehidupan bergantung pada gawai (gadget) [1].Permasalahan yang akan dibahas pada penelitian ini ada pada kaum milenial yang sudah berkeluarga atau sudah memiliki anak. Seperti yang kita ketahui kehadiran gawai dan revolusi industri 4.0 telah merubah bagaimana kaum milenial melaksanakan aktivitasnya sehari-hari (terdigitalisasi). Merujuk pada keterkaitan kaum milenial dan revolusi industri 4.0, kehadiran rumah konvensional yang sudah ada (eksisting) / tersedia didalam menjawab kemampuannya mewadahi daur hidup kaum milenial perkotaan yang telah berkeluarga menjadi dipertanyakan ke-ideal-annya. Dengan hadirnya aktivitas baru kaum milenial ini maka akan dapat melahirkan kebutuhan ruang baru. Merujuk pada pengertian rumah menurut undang-undang no.4 tahun 1992, bahwa rumah sebagai sarana pembinaan keluarga, penting untuk diketahui bagaimana daur hidup kaum milenial terkait pembinaan keluarga terjadi dalam rumah yang mereka huni saat ini. Fenomena ini menjadi isu menarik yang mengarahkan pada kebutuhan dilaksanakannya kajian ulang. Kajian ulang bersifat komparasi diperlukan untuk menemukan kebutuhan ruang dalam rumah yang paling optimal untuk mewadahi daur hidup kaum milenial berkeluarga yang selanjutnya dapat diefisiensikan dari sisi desain, kebutuhan lahan, dan biaya kedepannya. Dengan demikian, rumah dapat hadir dengan desain yang lebih efisien, sehingga menjadi suatu rumah ideal yang nyaman, layak huni, efektif, dan sesuai finansial bagi kaum milenial.

Sesuai dengan permasalahan terkait kaum milenial dengan aktivitasnya kini, maka dirumuskan pertanyaan penelitian sebagai berikut: (1) Ruang-ruang apa saja yang sebenarnya dibutuhkan dalam daur hidup keluarga kaum milenial perkotaan tersebut? (2) Sifat ruang yang seperti apa yang paling dibutuhkan bagi kaum milenial berkeluarga di Denpasar Timur? Tujuan pelaksanaan Kajian kebutuhan ruang bagi Kaum Milenial berkeluarga ini adalah : (1) Menemukan ruang-ruang yang paling esensial diperlukan bagi kaum milenial berkeluarga dalam desain rumah tinggal mereka lengkap dengan sifat dan kondisi yang dibutuhkan; (2) Memahami bagaimana keterkaitan antara aktivitas dalam siklus hidup dan gaya hidup kaum milenial berkeluarga serta dampaknya dalam menghasilkan tata ruang yang ideal.

Melalui kajian penelitian ini akan ditemukan aspek kebutuhan ruang yang holistik bagi kaum milenial berkeluarga perkotaan seperti: jenis ruang yang dibutuhkan, kondisi ruang, 
sifat ruang, dan tata guna ruangnya. Data-data ini berfokus pada Kebutuhan Ruang (jenis, sifat, kondisi, dan tata guna ruang) yang mampu memberikan kontribusi usulan desain ideal pengadaan rumah kaum milenial berkeluarga bagi para developer atau stakeholder pengadaan perumahan lain nantinya. Sehingga, kedepannya dapat membantu dalam pengadaan rumah ideal dengan aspek yang telah diperhitungkan secara rinci bagi keluargakeluarga milenial perkotaan yang tinggal di Kota Denpasar, khususnya di Kecamatan Denpasar Timur.

\section{Metodologi}

\subsection{Ruang Daur Hidup}

Menurut [2] ruang daur hidup (Life Cycle Space) dapat kita mengerti dalam kata perkata. Ruang, menurut Kamus Besar Bahasa Indonesia (KBBI) diartikan sebagai "rongga yang tidak berbatas tempat segala yang ada". Dalam bahasa inggris space berasal dari bahasa prancis kuno espace yang bermakna period of time, distance, interval. Berdasarkan bahasa latin yakni spatium yang bermakna room, area, distance, stretch of time. Berdasarkan pemahaman melalui kata per kata ruang dapat dimengerti sebagai sebuah lingkup area yang berkaitan dengan penggunaannya dalam periode waktu yang tetap atau bahkan insidentil. . Ruang daur hidup secara terminologi, selanjutnya dapat dipahami sebagai periode dari rangkaian kehidupan demi mempertahankan keberadaan kehidupan itu sendiri yang berlangsung didalam ruang dan waktu.Menurut [3], Perkembangan fisik dan usia dari manusia dapat mempengaruhi ruang kehidupan dimana manusia tersebut beraktivitas. Menurut [4] terdapat 8 tahapan daur hidup manusia antara lain:

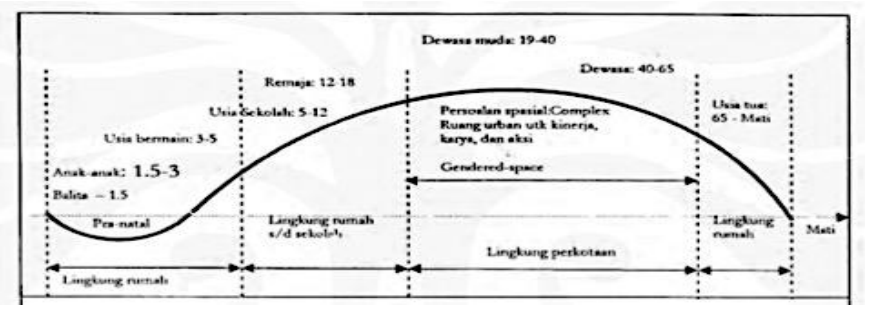

Gambar 1 Daur Hidup Manusia dan Implikasinya terhadap Ruang Kehidupan Manusia.

Sumber: Erikson dalam [3].

\subsection{Kebutuhan Ruang}

Didalam menemukan kebutuhan ruang terbaik bagi aktivitas manusia, kita harus memahami dengan cermat tentang perilaku mereka. Dalam menggali aktivitas, kondisi, dan karakteristik orang yang akan kita rancang ruangnya, kita harus dapat menggunakan waktu kita secara efektif dan melakukan hal - hal yang konstruktif.

\subsection{Ruang Fisikal}

Analisa kebutuhan ruang dibutuhkan dalam mendesain hal-hal mendasar dalam sebuah bangunan. Jika kita tidak mengetahui apa saja kebutuhan manusia, kita tidak dapat secara 
tepat mendesain bagi manusia. Kebutuhan fisik, merupakan kebutuhan yang mudah dipahami karena bersifat terukur. Kita dapat mengukur tinggi lemari gantung tempat penyimpanan di dapur, karena dapat diketahui jarak jangkau manusia agar mampu meraihnya dengan nyaman. Kita dapat mengukur peralatan yang akan ditempatkan diruang kosong, menambahkan perabot (furnitur) sesuai dengan jarak raih manusia, dan mempelajari ukuran yang sesuai pada ruang kosong tersebut. Ukuran manusia atau antropometrik merupakan pengukuran objektif dan didapatkan dalam proses ilmiah. Pengukuran ini akan mampu menghasilkan efek ruang yang diinginkan yang disebut ergonomik. Ergonomik terpahami sebagai ilmu yang mengusahakan lingkungan aktivitas yang paling optimal bagi manusia. Dengan demikian, aspek -aspek yang berpotensi mengganggu/menurunkan kinerja aktivitas dapat diantisipasi melalui desain lingkungan aktivitas, yang termasuk didalamnya adalah suhu, penerangan, suara, dan perabot (furnitur). Sebagai contoh, segala sesuatu yang ada disekitar kita sebenarnya sudah didesain secara kajian ergonomis seperti pakaian, kursi, aksesoris, hingga hal detail seperti gagang kulkas (yang mungkin muncul dalam pemikiran kita), secara rinci semua terdesain dengan fokus manusia sebagai pemakainya. Secara singkat dapat dipahami bahwa ruang fisikal dibuat untuk mengakomodasi perilaku dasar manusia.

\subsection{Ruang Psikososial}

Ruang atau lingkungan yang ditempati (fisikal) dan dilihat (visual), diharuskan untuk melalui perencanaan dengan analisa perilaku manusia dan fungsi apa saja yang mendukung sebuah ruang. Perilaku manusia bersifat psikologis dan sosial. Ruang personal, ruang personal dapat hadir dalam bentuk fisik maupun visual. Secara fisik, setiap orang membutuhkan besaran ruang tertentu disekitar mereka agar merasa aman dan nyaman. Jumlah dan bentuk ruang ini beragam, karena bergantung pada individu dan aktivitasnya. Dapat diumpamakan seperti : seseorang yang ada dalam kondisi percakapan dengan seorang sahabat, dapat merasa nyaman dengan jarak $45 \mathrm{~cm}$ diantara mereka. Tetapi, dilain hal, jarak ini dapat menjadi menimbulkan rasa tak tertahankan dalam sebuah pertemuan bisnis resmi dari 2 eksekutif perusahaan yang belum saling mengenal satu sama lain. Jarak yang dipilih oleh seseorang dapat mempengaruhi mood aktivitasnya. Jarak saling berdekatan dengan orang lain dapat memiliki pengaruh negatif. Sehingga ruang personal dapat dipahami sebagai sebuah wilayah/ruang yang mengelilingi seseorang dimana orang lainnya tidak diharapkan masuk kecuali diundang. Konsep dari ruang personal itu sendiri adalah setiap orang menuntut luas tertentu dari ruang yang ada disekitar mereka. Aspek yang perlu dipertimbangkan dalam kajian ruang personal seseorang adalah formalitas dan informalitas; kebudayaan; jarak kontak mata, jarak kontak fisik.

Metode penelitian yang digunakan adalah metode penelitian kualitatif. Menurut (Patton, 1990; Creswell, 2007) dengan mengunakan metode kualitatif peneliti dapat mempelajari permasalahan tertentu dengan lebih dalam dan rinci. Sesuai dengan tujuan dan target kajian, metode kualitatif digunakan untuk mendapatkan informasi yang bersifat dalam dan rinci dalam menjawab persoalan kebutuhan ruang dalam rumah bagi kaum milenial perkotaan di Kecamatan Denpasar Timur berbasis ruang daur hidupnya. Jenis penelitian yang dilakukan adalah penelitian deskriptif komparatif. Menurut Whitney (in Nazir, 1988)metode deskriptif adalah pencarian fakta dengan interpretasi yang tepat. Komparatif dengan membandingkan studi literatur dan kondisi eksisting studi kasus. 


\section{Hasil Dan Pembahasan}

\subsection{Preferensi Pemilihan Rumah}

Turner menyebutkan bahwa terdapat tiga fungsi utama yang terkandung dalam sebuah rumah dalam fungsinya sebagai tempat bermukim, yakni [8]:

1. Penunjang Identitas Keluarga (Identity): Perwujudan kualitas rumah

2. Penunjang Kesempatan (Opportunity): Rumah sebagai wadah untuk berkembang secara sosial-budaya dan ekonomi. Kemudahan menuju tempat kerja dan mendapatkan sumber penghasilan.

3. Penunjang Rasa Aman (Security): jaminan keamanan terkait masa depan keluarga, jaminan keamanan lingkungan, dan jaminan keamanan dari kepemilikan tanah untuk rumah.

Penggalan diatas menjelaskan bahwa ruang-ruang yang ada dalam rumah mampu memiliki pengertian yang luas dan berbeda-beda bagi tiap individu. Berdasarkan pemahaman tersebut, dapat dipahami bahwa karakteristik tiap individu tentunya akan membawa tata ruang dan kebutuhan ruang yang berbeda bergantung pada orientasi kebutuhan dan prioritas dari masing-masing individu. Jika ditelaah dengan lebih dalam maka, karakteristik dari kaum milenial berkeluarga dapat pula berpengaruh terhadap tata guna ruang dan susunan ruang yang ada didalam rumah mereka dan seberapa penting dan nyamankah ruang tersebut bagi mereka.

\subsection{Karakteristik Generasi Milenial}

Selanjutnya adalah analisa literatur untuk dapat memahami generasi milenial beserta karakteristiknya. Ciri utama dari generasi milenial ini adalah generasi yang memiliki kelahiran pada rentang tahun 1983-2001 [9]. Generasi milenial Indonesia rata-rata mengenyam Pendidikan tinggi, hal ini memberikan mereka pola pikir yang kreatif.

Adapun beberapa karakteristik dari generasi milenial adalah (Kemen PPPA \& Badan Pusat Statistik, 2018):

1. Beragam Profesi, Para generasi milenial memiliki banyak profesi.

2. Karakteristik Unik, Memiliki karakteristik unik berbeda-beda bergantung pada kondisi wilayah dan sosial-ekonomi.

3. Akrab Teknologi-Produktif: Peningkatan keakraban dengan komunikasi, media, dan teknologi digital Penggunaan Gadget membuat millennials lebih produktif.

4. Kreatif : melalui keakrabannya dengan teknologi dan media digital mereka mampu menciptakan peluang-peluang baru melalui pesa singkat, media sosial (e-commerce)

5. Pola piker open-minded: pola pikir yang terbuka khususnya pada perekonomian, politik, dan pemerintahan.

6. Passionate Person

Keenam karakteristik diatas selanjutnya difokuskan kembali menjadi karakteristik kaum milenial yang dapat mempengaruhi aktivitas meruang. 


\begin{tabular}{|c|l|l|}
\hline No. & Karakteristik & Pengaruh Terhadap Ruang Dalam Rumah \\
\hline $\mathbf{1}$ & $\begin{array}{l}\text { Akrab Teknologi- } \\
\text { Produktif }\end{array}$ & $\begin{array}{l}\text { Minimnya penggunaan ruang akibat sudah terwadahi oleh teknologi } \\
\text { Terciptanya peluang hadirnya ruang-ruang baru dalam rumah guna } \\
\text { mengakomodasi kebutuhan digital }\end{array}$ \\
\hline $\mathbf{2}$ & Kreatif & $\begin{array}{l}\text { Adanya re-konfigurasi penggunaan ruang atau tata guna ruang dalam } \\
\text { rumah, sehingga ruang-ruang tidak hanya mewadahi fungsi utama }\end{array}$ \\
\hline
\end{tabular}

Selanjutnya, karakteristik diatas digunakan sebagai media komparasi dan analisis lebih mendalam terkait data yang ditemukan dilapangan baik data hasil kuisioner maupun observasi langsung.

\subsection{Daur Hidup Kaum Milenial Berkeluarga di Denpasar Timur}

Selain daripada Analisa dari literature terkait, penelitian ini juga menggunakan kuisioner, kuisioner yang disebarkan ke beberapa generasi milenial berkeluarga di kota Denpasar, khususnya Denpasar timur.

\begin{tabular}{|c|c|c|c|c|}
\hline No & Kategori & Mayoritas & Presentase & $\begin{array}{c}\text { Jumlah } \\
\text { Responden }\end{array}$ \\
\hline 1 & Umur & 28 Tahun & $41.7 \%$ & 10 \\
\hline 2 & Pekerjaan & Wiraswasta & $41.7 \%$ & 10 \\
\hline 3 & Tipikal lokasi rumah & Rumah dalam perumahan & $50 \%$ & 12 \\
\hline 4 & Anggota keluarha serumah & $\begin{array}{l}1 \text { istri/suami dengan } 2 \\
\text { anak ( } 4 \text { orang) }\end{array}$ & $45.8 \%$ & 11 \\
\hline 5 & Tinggal dengan orang tua & Bersama ayah dan Ibu saja & $87.5 \%$ & 21 \\
\hline 6 & $\begin{array}{l}\text { Responden beraktivitas di } \\
\text { rumah pada hari senin- } \\
\text { Jumat }\end{array}$ & Malam hari saja & $45.8 \%$ & 11 \\
\hline 7 & $\begin{array}{l}\text { Anak-anak responden } \\
\text { beraktivitas di rumah pada } \\
\text { hari senin-jumat }\end{array}$ & Pagi hingga malam hari & $33.3 \%$ & 8 \\
\hline 8 & $\begin{array}{l}\text { Pasangan responden } \\
\text { beraktivitas di rumah pada } \\
\text { hari senin-jumat }\end{array}$ & Pagi hingga malam hari & $45.8 \%$ & 11 \\
\hline 9 & $\begin{array}{l}\text { Responden beraktivitas di } \\
\text { rumah pada hari senin-jumat }\end{array}$ & Pagi hingga malam hari & $50 \%$ & 12 \\
\hline 10 & $\begin{array}{l}\text { Pasangan responden } \\
\text { beraktivitas di rumah pada } \\
\text { hari senin-jumat }\end{array}$ & Pagi hingga malam hari & $54.2 \%$ & 13 \\
\hline
\end{tabular}




\begin{tabular}{|c|l|c|l|l|}
\hline No & \multicolumn{1}{|c|}{ Kategori } & Mayoritas & Presentase & $\begin{array}{c}\text { Jumlah } \\
\text { Responden }\end{array}$ \\
\hline 11 & $\begin{array}{l}\text { Anak-anak responden } \\
\text { beraktivitas di rumah pada } \\
\text { hari senin-jumat }\end{array}$ & Pagi hingga malam hari & $54.2 \%$ & 13 \\
\hline
\end{tabular}

Dari tabel di atas dapat disimpulkan bahwa:

1. Mayoritas responden tinggal dengan orang tua mereka beserta keluarga mereka sendiri (6 orang: Responden, Istri/Bapak, Anak 1, Anak 2, Ayah/Ayah Mertua Responden dan Ibu/Ibu Mertua Responden).

2. Mayoritas tinggal pada lingkungan residensial atau perumahan terencana,

3. Aktivitas orang tua (Responden Beserta Pasangan) yang cukup padat pada hari senin hingga jumat sehingga hanya mampu beraktivitas pada malam hari.

4. Aktivitas anak responden dari hari senin-minggu mayoritas ada didalam rumah karena mayoritas umur anak responden ada pada usia bayi hingga balita yang notabene belum mampu beraktivitas diluar rumah secara maksimal.

5. Aktivitas Responden beserta Pasangan didalam rumah baru terlaksana maksimal pada hari Sabtu dan Minggu, dimana pada hari ini merupakan hari libur dan mereka memanfaatkan untuk bercengkrama bersama dengan keluarga.

Berdasarkan kesimpulan diatas, maka (1) Daur Hidup responden sebenarnya tidak membutuhkan ruang-ruang yang secara spesifik hadir guna mewadahi aktivitas tertentu didalam rumah mereka, karena aktivitas mereka terbilang lebih padat diluar rumah setiap minggunya. Mengacu kepada ruang daur hidup diatas dapat pula ditarik kesimpulan bahwa (2) Ruang-ruang yang sekiranya diperlukan adalah ruang-ruang yang dipergunakan pada kurun waktu dimana sebagian besar aktivitas anggota keluarga memang sedang berada dirumah yakni senin-jumat pada pagi dan malam hari, kemudian di hari Sabtu dan Minggu Pagi hingga malam hari. Dengan menerapkan hasil Analisa diatas ditambah dengan Analisa tata guna ruang selanjutnya, diharapkan dapat ditemukan ruang-ruang yang efisien yang dapat hadir guna mewadahi aktivitas kaum milenial berkeluarga.

\subsection{Tata Guna Ruang Dalam Rumah Kaum Milenial Berkeluarga Denpasar Timur}

Pada bagian ini dibahas hasil pendataan kuisioner berdasarkan hasil rinci maisng-masing responden terkait keberadaan ruang dan penggunaannya. Pada beberapa responden terdapat photo kondisi ruang-ruang dalam rumahnya guna mempertajam kebenaran data hasil observasi. 


\begin{tabular}{|c|c|c|c|c|c|}
\hline Responden & & $\begin{array}{l}\text { Ruang } \\
\text { yang } \\
\text { Dimodifi } \\
\text { kasi }\end{array}$ & $\begin{array}{l}\text { Bentuk Modifikasi } \\
\text { (Tambah } \\
\text { Fungsi/Pengadaan } \\
\text { Ruang Non- } \\
\text { Konvensional) }\end{array}$ & $\begin{array}{l}\text { Ruang Tanpa } \\
\text { Modifikasi }\end{array}$ & $\begin{array}{l}\text { Tata Guna } \\
\text { Ruang } \\
\text { Tidak } \\
\text { Nyaman }\end{array}$ \\
\hline R1: Perawat & 2 & Garase & $\begin{array}{l}\text { Ruang produksi } \\
\text { Toko }\end{array}$ & $\begin{array}{l}\text { KT, KM, Teras, R. } \\
\text { Keluarga, R. Tamu, } \\
\text { Ruang Terbuka }\end{array}$ & $\begin{array}{l}\text { Garase } \\
\text { Dapur }\end{array}$ \\
\hline $\begin{array}{l}\text { R2: Karyawan } \\
\text { Swasta }\end{array}$ & & Tidak ada & & & \\
\hline R3: Perawat & 1 & Garase & Toko & $\begin{array}{l}\text { KT, KM, Teras, } \\
\text { Dapur, R. Keluarga, } \\
\text { R. Tamu, Ruang } \\
\text { Terbuka }\end{array}$ & \\
\hline \multirow[t]{2}{*}{ R4: Arsitek } & 1 & $\begin{array}{l}\text { Kamar } \\
\text { Tidur }\end{array}$ & Ruang kerja & \multirow{2}{*}{$\begin{array}{l}\text { KT, KM, Teras, } \\
\text { Dapur, R. Keluarga, } \\
\text { R. Tamu, Ruang } \\
\text { Terbuka }\end{array}$} & $\begin{array}{l}\text { Kamar } \\
\text { tidur }\end{array}$ \\
\hline & 2 & Garase & $\begin{array}{l}\text { Workshop dan } \\
\text { Gudang }\end{array}$ & & Garase \\
\hline \multirow[t]{2}{*}{ R5: Perawat } & 1 & $\begin{array}{l}\text { Ruang } \\
\text { Tamu }\end{array}$ & Ruang Meeting & \multirow{2}{*}{$\begin{array}{l}\text { KT, KM, Teras, } \\
\text { Dapur, R. Keluarga, } \\
\text { R. Tamu, Ruang } \\
\text { Terbuka }\end{array}$} & \\
\hline & 2 & Garase & Toko & & \\
\hline $\begin{array}{l}\text { R6: Karyawan } \\
\text { Swasta }\end{array}$ & 1 & Garase & workshop & $\begin{array}{l}\text { KT, KM, Teras, } \\
\text { Dapur, R. Keluarga, } \\
\text { R. Tamu, Ruang } \\
\text { Terbuka }\end{array}$ & Garase \\
\hline \multirow[t]{2}{*}{ R7: Photografer } & 1 & $\begin{array}{l}\text { Ruang } \\
\text { Keluarga }\end{array}$ & Ruang Meeting & \multirow{2}{*}{$\begin{array}{l}\text { KT, KM, Teras, } \\
\text { Dapur, Garase, } \\
\text { Ruang Terbuka }\end{array}$} & $\begin{array}{l}\text { Ruang } \\
\text { Keluarga }\end{array}$ \\
\hline & 2 & $\begin{array}{l}\text { Ruang } \\
\text { Tamu }\end{array}$ & Ruang Editing foto & & $\begin{array}{l}\text { Ruang } \\
\text { Tamu }\end{array}$ \\
\hline \multirow[t]{2}{*}{$\begin{array}{l}\text { R8: } \\
\text { Arsitek/Interior }\end{array}$} & 1 & $\begin{array}{l}\text { Ruang } \\
\text { keluarga }\end{array}$ & Ruang meeting & \multirow{2}{*}{$\begin{array}{l}\text { KT, KM, Teras, } \\
\text { Dapur, R. Tamu, } \\
\text { Ruang Terbuka }\end{array}$} & $\begin{array}{l}\text { R. } \\
\text { Keluarga }\end{array}$ \\
\hline & 2 & Garase & $\begin{array}{l}\text { Kantor Konsultan } \\
\text { Desain }\end{array}$ & & Garase \\
\hline \multirow[t]{2}{*}{ R9: wiraswasta } & 1 & $\begin{array}{l}\text { Ruang } \\
\text { Kerja }\end{array}$ & $\begin{array}{l}\text { Penambahan } \\
\text { Ruangan }\end{array}$ & \multirow{2}{*}{$\begin{array}{l}\text { KT, KM, Teras, } \\
\text { Dapur, R. Keluarga, } \\
\text { R. Tamu, Ruang } \\
\text { Terbuka }\end{array}$} & \\
\hline & 2 & Garase & Toko dan Gudang & & Garase \\
\hline R10: & 1 & Garase & workshop & $\begin{array}{l}\text { KT, KM, Teras, } \\
\text { Dapur, R. Keluarga, }\end{array}$ & Garase, \\
\hline
\end{tabular}




\begin{tabular}{|c|c|c|c|c|c|}
\hline Responden & & $\begin{array}{l}1 \\
\text { Ruang } \\
\text { yang } \\
\text { Dimodifi } \\
\text { kasi }\end{array}$ & $\begin{array}{l}2 \\
\text { Bentuk Modifikasi } \\
\text { (Tambah } \\
\text { Fungsi/Pengadaan } \\
\text { Ruang Non- } \\
\text { Konvensional) }\end{array}$ & $\begin{array}{l}3 \\
\text { Ruang Tanpa } \\
\text { Modifikasi }\end{array}$ & $\begin{array}{l}4 \\
\text { Tata Guna } \\
\text { Ruang } \\
\text { Tidak } \\
\text { Nyaman }\end{array}$ \\
\hline wiraswasta & & & & $\begin{array}{l}\text { R. Tamu, Ruang } \\
\text { Terbuka }\end{array}$ & Taman \\
\hline $\begin{array}{l}\text { R11: } \\
\text { wiraswasta }\end{array}$ & 1 & Garase & Toko & $\begin{array}{l}\text { KT, KM, Teras, } \\
\text { Dapur, R. Keluarga, } \\
\text { R. Tamu, Ruang } \\
\text { Terbuka }\end{array}$ & $\begin{array}{l}\text { Garase, } \\
\text { Taman }\end{array}$ \\
\hline $\begin{array}{l}\text { R12: } \\
\text { wiraswasta }\end{array}$ & 1 & Garase & Toko & $\begin{array}{l}\text { KT, KM, Teras, } \\
\text { Dapur, R. Keluarga, } \\
\text { R. Tamu, Ruang } \\
\text { Terbuka }\end{array}$ & $\begin{array}{l}\text { Garase, } \\
\text { Taman }\end{array}$ \\
\hline $\begin{array}{l}\text { R13: } \\
\text { wiraswasta }\end{array}$ & 1 & Garase & workshop & $\begin{array}{l}\text { KT, KM, Teras, } \\
\text { Dapur, R. Keluarga, } \\
\text { R. Tamu, Ruang } \\
\text { Terbuka }\end{array}$ & $\begin{array}{l}\text { Garase, } \\
\text { Taman }\end{array}$ \\
\hline $\begin{array}{l}\text { R14: } \\
\text { wiraswasta }\end{array}$ & 1 & Garase & Galeri & $\begin{array}{l}\text { KT, KM, Teras, } \\
\text { Dapur, R. Keluarga, } \\
\text { R. Tamu, Ruang } \\
\text { Terbuka }\end{array}$ & $\begin{array}{l}\text { Garase, } \\
\text { Taman }\end{array}$ \\
\hline $\begin{array}{l}\text { R15: } \\
\text { wiraswasta }\end{array}$ & 1 & Garase & Gudang & $\begin{array}{l}\text { KT, KM, Teras, } \\
\text { Dapur, R. Keluarga, } \\
\text { R. Tamu, Ruang } \\
\text { Terbuka }\end{array}$ & Garase \\
\hline $\begin{array}{l}\text { R16: } \\
\text { wiraswasta }\end{array}$ & 1 & Garase & Gudang & $\begin{array}{l}\text { KT, KM, Teras, } \\
\text { Dapur, R. Keluarga, } \\
\text { R. Tamu, Ruang } \\
\text { Terbuka }\end{array}$ & Garase \\
\hline $\begin{array}{l}\text { R17: } \\
\text { wiraswasta }\end{array}$ & 1 & Garase & Gudang & $\begin{array}{l}\text { KT, KM, Teras, } \\
\text { Dapur, R. Keluarga, } \\
\text { R. Tamu, Ruang } \\
\text { Terbuka }\end{array}$ & Garase \\
\hline $\begin{array}{l}\text { R18: Arsitek } \\
\text { Freelance }\end{array}$ & 1 & $\begin{array}{l}\text { Ruang } \\
\text { Studio } \\
\text { Gambar }\end{array}$ & Penambahan Ruang & $\begin{array}{l}\text { KT, KM, Teras, } \\
\text { Dapur, R. Keluarga, } \\
\text { R. Tamu, Ruang } \\
\text { Terbuka }\end{array}$ & R. Kerja \\
\hline R19: Arsitek & 1 & Ruang & Penambahan Ruang & KT, KM, Teras, & R. Kerja \\
\hline
\end{tabular}




\begin{tabular}{|c|c|c|c|c|c|}
\hline Responden & & $\begin{array}{l}1 \\
\text { Ruang } \\
\text { yang } \\
\text { Dimodifi } \\
\text { kasi }\end{array}$ & $\begin{array}{l}2 \\
\text { Bentuk Modifikasi } \\
\text { (Tambah } \\
\text { Fungsi/Pengadaan } \\
\text { Ruang Non- } \\
\text { Konvensional) }\end{array}$ & $\begin{array}{l}3 \\
\text { Ruang Tanpa } \\
\text { Modifikasi }\end{array}$ & $\begin{array}{l}4 \\
\text { Tata Guna } \\
\text { Ruang } \\
\text { Tidak } \\
\text { Nyaman }\end{array}$ \\
\hline Freelance & & $\begin{array}{l}\text { Studio } \\
\text { Gambar }\end{array}$ & & $\begin{array}{l}\text { Dapur, R. Keluarga, } \\
\text { R. Tamu, Ruang } \\
\text { Terbuka }\end{array}$ & \\
\hline $\begin{array}{l}\text { R20: Arsitek } \\
\text { Freelance }\end{array}$ & 1 & $\begin{array}{l}\text { Ruang } \\
\text { Studio } \\
\text { Gambar }\end{array}$ & Penambahan Ruang & $\begin{array}{l}\text { KT, KM, Teras, } \\
\text { Dapur, R. Keluarga, } \\
\text { R. Tamu, Ruang } \\
\text { Terbuka }\end{array}$ & R. Kerja \\
\hline $\begin{array}{l}\text { R21: } \\
\text { Wiraswasta }\end{array}$ & 1 & $\begin{array}{l}\text { Ruang } \\
\text { Bekerja }\end{array}$ & Penambahan Ruang & $\begin{array}{l}\text { KT, KM, Teras, } \\
\text { Dapur, R. Keluarga, } \\
\text { R. Tamu, Ruang } \\
\text { Terbuka }\end{array}$ & \\
\hline $\begin{array}{l}\text { R22: } \\
\text { Wiraswasta }\end{array}$ & 2 & $\begin{array}{l}\text { Babersho } \\
\text { p }\end{array}$ & $\begin{array}{l}\text { Coffe shop } \\
\text { Penambahan ruang }\end{array}$ & $\begin{array}{l}\text { KT, KM, Teras, } \\
\text { Dapur, R. Keluarga, } \\
\text { R. Tamu, Ruang } \\
\text { Terbuka }\end{array}$ & Teras \\
\hline $\begin{array}{l}\text { R23: } \\
\text { Wiraswasta }\end{array}$ & 1 & Garase & Caffe & $\begin{array}{l}\text { KT, KM, Teras, } \\
\text { Dapur, R. Keluarga, } \\
\text { R. Tamu, Ruang } \\
\text { Terbuka }\end{array}$ & Garase \\
\hline R24: Dosen & 1 & $\begin{array}{l}\text { Ruang } \\
\text { Percetak } \\
\text { an }\end{array}$ & Penambahan ruang & $\begin{array}{l}\text { KT, KM, Teras, } \\
\text { Dapur, R. Keluarga, } \\
\text { R. Tamu, Ruang } \\
\text { Terbuka }\end{array}$ & $\begin{array}{l}\text { R. } \\
\text { Percetakan }\end{array}$ \\
\hline
\end{tabular}

Berdasakan tabulasi kesimpulan tata guna ruang dapat ditemukan rekonfigurasi ruang pada hamper setiap responden yang diakibatkan oleh profesi yang digeluti oleh responden tersebut baik penujang maupun profesi utama. Rekonfigurasi ruang ini sendiri terjadi secara penambahan ruang dan penyekatan atau menambahkan fungsi pada ruang-ruang yang memang sudah ada. Sebagian besar rekonfigurasi ruang dilaksakan pada area public hingga semi public. Tindakan para kaum milenial berkeluarga ini memberikan dampak negative yakni ketidaknyamanan dalam penggunaan ruang, karena mereka memaksakan ruang yang sudah ada agar dapat dimanfaatkan untuk fungsi lain guna menunjang kebutuhan hidup mereka. 

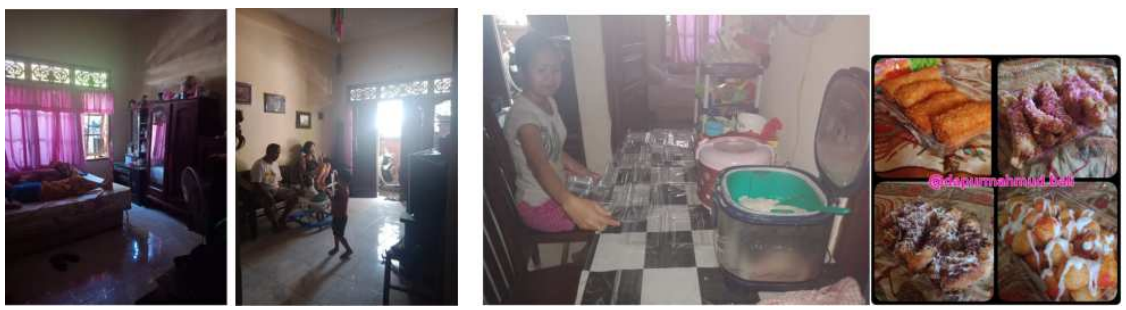

Gambar 2 Kiri-Kanan Suasana Rumah Responden I: Fasad, Kamar Mandi, Kamar Tidur; Ruang Keluarga; Garase/Carport; Dapur

Sumber: Data Peneliti, 2019
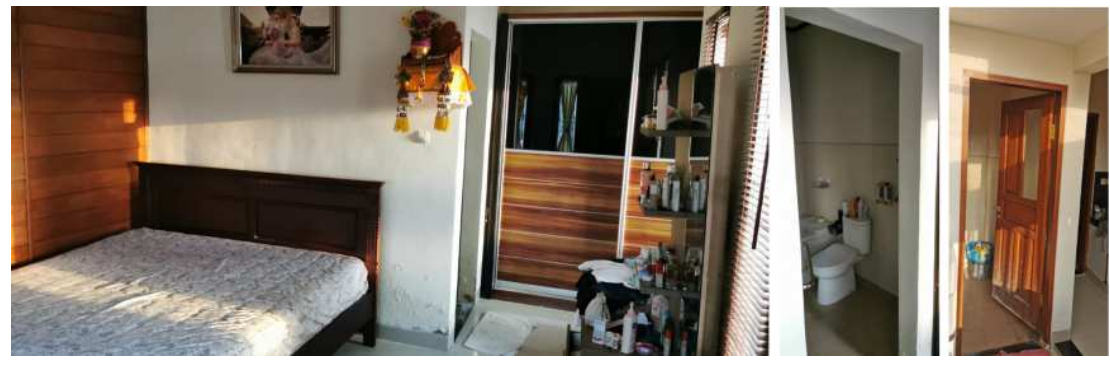

Gambar 3 Kiri-Kanan Suasana Rumah Responden II: Kamar Tidur, Kamar Mandi, Ruang Keluarga. Sumber: Data Peneliti, 2019

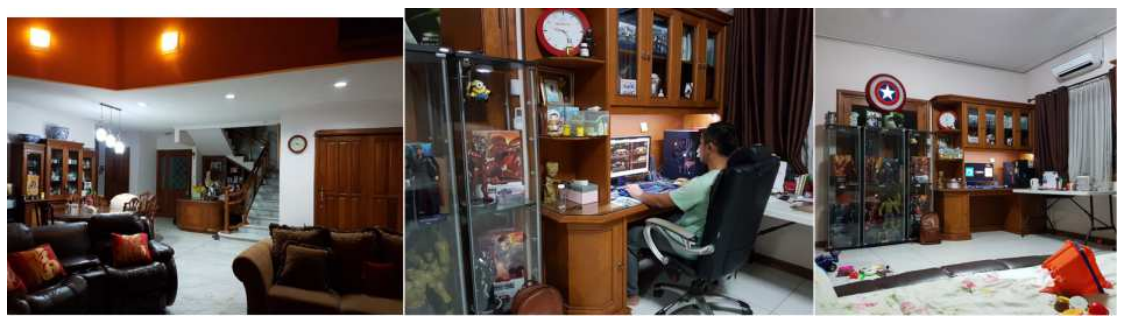

Gambar 4Kiri-Kanan Suasana Rumah Responden IV:Ruang Keluarga dan Kamar Tidur Sumber: Data Peneliti, 2019

\section{Kesimpulan}


Berdasarkan pemaparan data dan hasil analysis di atas dapat disimpulkan bahwa kebutuhan ruang rumah bagi kaum milenial berkeluarga di DenpasarTimur adalah 1) Ruangruang dalam rumah kaum milenial harus mampu menunjang kebutuhan kreatifitas mereka didalam memenuhi kebutuhan hidup seperti mengakomodasi bisnis sampingan, atau dapat memanfaatkan Rumah sebagai Penunjang Kesempatan (Opportunity) dalam bertahan hidup. 2) Daur hidup kaum milenial yang cukup padat memberikannya waktu dirumah hanya pada malam hari pada hari kerja dan sabtu minggu pada hari libur. Bagi yang memiliki bisnis sampingan mereka akan mempergunakan hari tidak bekerja untuk menjalankan bisnis sehingga beberapa ruang dapat diefisiensikan guna memaksimalkan kebutuhan kaum milenial dalam berbisnis. 3) Karakteristik Kaum Milenial yang kreatif dan akrab teknologi memungkinkan adanya rekonfigurasi ruang, sehingga keadaan ini harus dapat diantisipasi dengan tata ruang rumah yang dapat berkembang dan dimasuki atau ditambahkan fungsi baru sehingga bersifat fleksibel.

Dari kesimpulan tersebut ditemukan bahwa detail ruang-ruang yang dibutuhkan kaum milenial berkeluarga adalah:

1. Ruang yang konvensional (Private), ruang yang fungsi utamanya tidak mengalami rekonfigurasi oleh responden: Kamar Tidur, Kamar Mandi, Ruang Keluarga

2. Ruang yang fleksibel (Publik - Semi Publik), atau ruang yang dapat berkembang sesuai kebutuhan: Ruang Tamu, Garase, Teras, Taman.

Jadi, didalam merancang desain rumah bagi kaum milenial berkeluarga sebaiknya mempertimbangkan desain rumah yang bersifat tetap pada ruang-ruang privat, dan berkembang pada ruang-ruang public guna mengakomodasi kreativitas, kesempatan berkembang (opportunity), dalam daur hidup kaum milenial berkeluarga.

\section{References}

[1] H. D. Rupa, Berfilsafat dalam Revolusi Industri 4.0. 2019.

[2] H. Firzandy, "Style Perancang dalam Kajian Arsitektur Berdasarkan Teori Kepribadian," Res. Gate, vol. IX, no. 1, pp. 75-86, 2016.

[3] I. Desiyana, Dome Bagi Korban Gempa di Ngelepen Yogyakarta: Suatu Kajian Terhadap Berhuni Dalam Rumah Hasil Bantuan Pasca Bencana. Depok: Departemen Arsitektur Universitas Indonesia, 2008.

[4] E. H. Erikson, The Life Cycle Completed. New York: W.W. Norton \& Company, 1997.

[5] M. Patton, Qualitative evaluation and research methods (pp. 169-186). Newbury Park: SAGE Publications, 1990.

[6] J. Creswell, Qualitative Inquiry \& Research Design: Choosing Among Five Approaches, 2nd ed. California: Sage Publication, 2007.

[7] M. Nazir, Metode Penelitian. Jakarta: Ghalia Indonesia, 1988.

[8] U. Jaenudin and R. Marliani, Psikologi Lingkungan. Jakarta: Pustaka Setia, 2017.

[9] E. D. Carlson, The Lucky Few: Between the Greatest Generation and the Baby Boom. Netherlands: Springer Science, 2008.

[10] Badan Pusat Statistik Jakarta Pusat. (2018). Kota Denpasar Dalam Angka. Kota Denpasar: Badan Pusat Statistik 